\title{
NATURAL REGENERATION STATUS OF CHILGOZA PINE (PINUS GERARDIANA WALL.) IN HIMACHAL PRADESH, INDIA: AN ENDANGERED PINE OF HIGH EDIBLE VALUE
}

\author{
MALIK, A.R. ${ }^{1}{ }^{*}-$ SHAMET, G.S. ${ }^{2}-$ BUTOLA, J.S. ${ }^{3}$ \\ ${ }^{1}$ Sheri-Kashmir University of Agricultural Science and Technology, \\ Shalimar-K-191 121 (J\&K), India \\ (phone: + 91-9797711194) \\ ${ }^{2}$ Dr. Y. S. Parmar University of Horticulture and Forestry, \\ Nauni, Solan-173230 (Himachal Pradesh), India \\ ${ }^{3}$ G.B. Pant Institute of Himalayan Environment and Development, \\ Kosi-Katarmal, Almora-263 643 (Uttarakhand), India \\ *Corresponding author \\ e-mail:malikrashid2@gmail.com or butolajs@rediffmail.com \\ (Received $8^{\text {th }}$ July 2008; accepted $10^{\text {th }}$ February 2012)
}

\begin{abstract}
Pinus gerardiana Wall. locally known as 'chilgoza' is near endemic and endangered to Himalayan region. The species has aptly been described as the "Champion of Rocky Mountains" as it grows under extremely rough site conditions. Being a flavorsome wild edible, the chilgoza pine nuts have high demand in local, national and international markets and fetch very high prices. Due to rampant harvesting of cones, natural regeneration of this species is being fatally hampered. In present study, the natural regeneration assessment of the species was conducted in the forests of Kinnuar of Himachal Pradesh, India. The whole distribution area of the species was divided into three zones, viz., Dry temperate, Semi arid and Arid. The sampling plots of $20 \mathrm{~m} \times 20 \mathrm{~m}$ were selected in which the regeneration sampling quadrates of $2 \mathrm{~m} \times 2 \mathrm{~m}$ were laid in the eastern and western bank of river Sutlej. The results revealed that the semiarid zone on the western aspect of the area have maximum established regeneration of the species (291.66 plants/ha). Overall, the mean natural regeneration status of the species was very poor $(15 \%)$. Thus, the species is facing higher risk of extinction and needs to be considered as 'Critically Endangered' in Indian Himalayan Region. It is suggested here that a suitable strategy and action plan including sustainable harvesting methods should be prepared and implemented on priority basis.
\end{abstract}

Keywords: Pinus gerardiana, natural regeneration, status, endangered, Himachal Pradesh

\section{Introduction}

Conifers are valuable natural resources of India, which contribute substantially to its socio-economic development by providing goods and services to the people and industries. They generate considerable revenue and also play a major role in enhancing the quality of environment by influencing the basic life support system. One of them, Pinus gerardiana Wall. named after its discoverer, Captain Gerard, is a small to medium sized evergreen tree. Its branches are short and horizontal forming compact habit, while bark is thin, glabrous, silver grey, having mottled appearance and often exfoliating in irregular, thin scales (Gupta and Sharma, 1975). Cones are oblong, ovoid and glaucous when mature while scales are thick, woody and reflexed (Gamble, 1902). The species is commonly known as "chilgoza or neoza pine". Its distribution is very sparse in the world, confined only to mountains of eastern Afghanistan, Pakistan, India and other scattered localities in the Hindu Kush Himalaya $\left(30^{\circ}\right.$ to $37^{\circ} \mathrm{N}$ latitude and $66^{\circ}$ 
to $80^{\circ} \mathrm{E}$ longitude). In India, it occurs in North-west Himalaya ranges from $31^{\circ} 55^{\prime}$ to $32^{\circ} 05^{\prime} \mathrm{N}$ latitude and $77^{\circ} 45^{\prime}$ to $79^{\circ} 35^{\prime} \mathrm{E}$ longitude (Chib, 1978) and grows between 1600 and $3300 \mathrm{~m}$ amsl. It is the only conifer in India which provides edible nuts/kernels rich in carbohydrate, proteins, fat, moisture, fiber and mineral matter. The chilgoza pine nuts fetch very high price ranging from Rs. 400-650/kg in the open market (personal survey, 2005-07) (Malik, 2007) and play an important role in socio-economic uplift of the people in tribal areas of Himachal Pradesh and Jammu and Kashmir (Sehgal and Khosla, 1986). The species has aptly been described as the "Champion of Rocky Mountains" as it grows under difficult sites conditions as prevailing in the inner Himalaya. The species occurs in dry temperate region experiences low temperature and scanty precipitation received mostly in the form of snow during winter. Besides, the species is an excellent soil binder and prevent large scale soil erosion from the otherwise lose and fragile strata in the region. The area under chilgoza forest has already shrunk to about 2000 hectares in Himachal Pradesh because each and every cone is lopped by local peoples as they have the right of chilgoza collection from natural forest, leaving very little for natural regeneration (Tandon, 1963; Singh et al. 1973; Sehgal and Sharma, 1989). The species is facing higher risk of extinction and therefore, categorized as Endangered in the Himalayan region (Sehgal and Sharma, 1989) and also listed in Red Data Book (Dogra, 1964). A detailed perusal of literature indicated that the information on propagation, storage condition, biochemical attributes of seeds and nursery development of the species is available (Malik, 2007; Singh and Chaudhary, 1993; Singh et al. 1992; Sharma, 2005; Malik et al. 2008; Malik and Shamet, 2008; Malik et al. 2009). However, there is very little information available on natural regeneration of the species (Singh et al. 1973; Sehgal and Sharma, 1989; Reddy, 1963). The understory plant regeneration is important and has increasingly been the subject of research in recent years (Leoppold et al. 2001; Smale et al. 2001; Hardwick et al. 2004; Carnus et al. 1979). Keeping this in view, need is being felt to study the present status of natural regeneration of the species so that effective steps can be taken for its conservation and sustainable utilization. The main objective of this study is therefore, to assess whether or not there is adequate regeneration (seedling or established growth) of this species in Kinnuar, Himachal Pradesh, India.

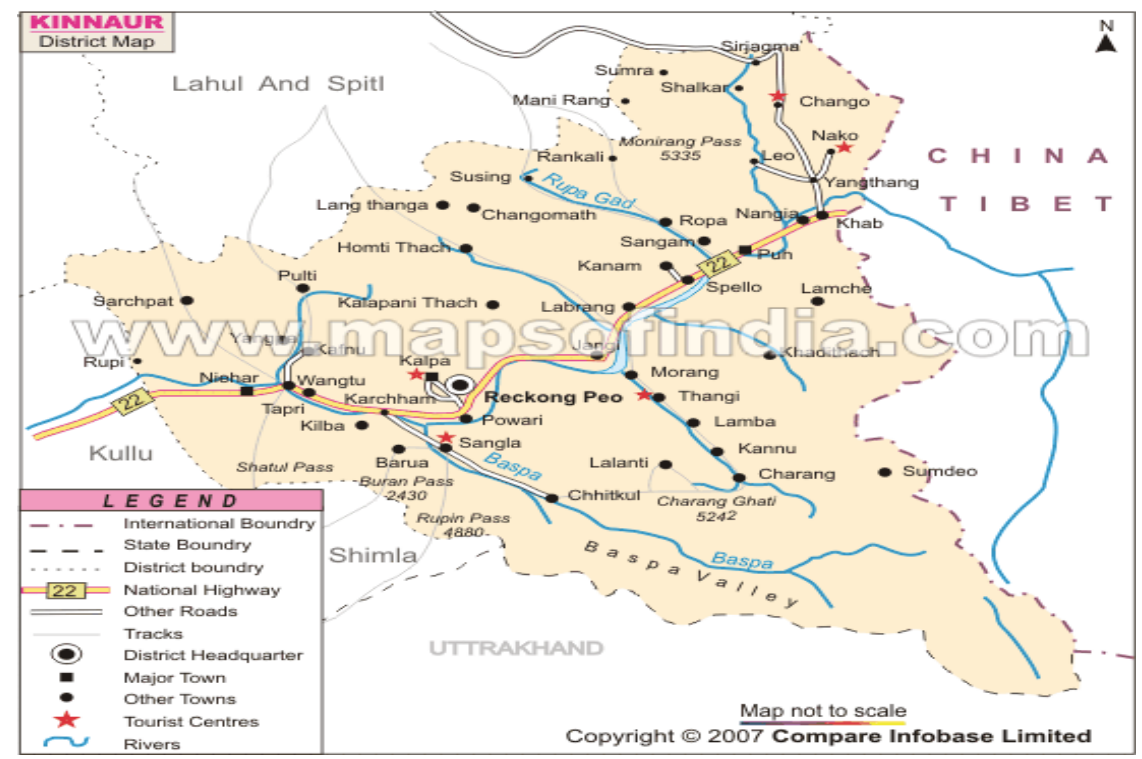

Figure 1. Map of Kinnaur district distribution zone of Pinus gerardiana 


\section{Description of study area}

The present study was carried out in chilgoza forest in district Kinnaur covering the whole distribution zone of species. The area lies in the dry temperate zone which is located in the north-eastern part of Himachal Pradesh, India (Fig. 1).

The study area exhibits dry temperate climate characterized by long winters from October to April and short summers from June to August. Though rain is scanty, precipitation is received mostly in the form of snow during winter. The data pertaining to meteorological conditions of the area during the study period are presented (Fig. $2 a$ $\& 2 b)$.
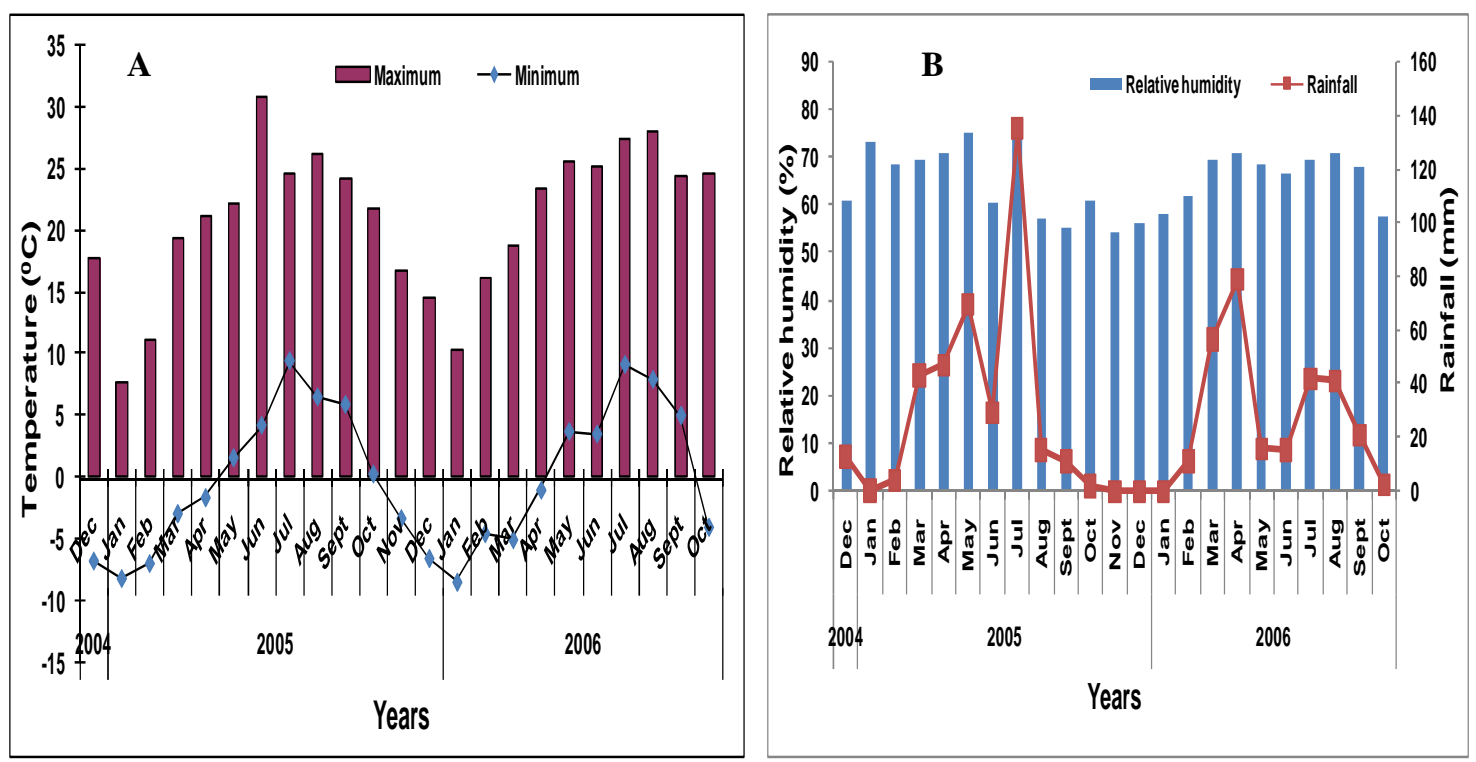

Figure 2. Meteorological data of Kinnaur during study period from December 2004 to October 2006 [A=Temperature $\left({ }^{\circ} \mathrm{C}\right) ; B=$ Relative humidity $(\%)$ and Rainfall $\left.(\mathrm{mm})\right]$

\section{Materials and Methods}

The regeneration status of $P$. gerardiana was assessed by dividing the whole distribution area of the species into three zones, viz., lower dry temperate zone (Tapri and Shongthong), mid semi-arid zone (Peo, Kalpa, Pangi, Powari upper and Ribba) and upper arid zone (Akpa, Jangi, Leepa, Moorang and Purbani). Each zone was further divided into sub zones based upon elevation and aspect by laying quadrates on both sides, i.e., eastern/right and western/left banks of the river Sutlej. The following methodology was adopted to assess regeneration status of the species:

\begin{tabular}{c|l|l}
\hline Sr. No. & Parameters & Nos. \\
\hline a. & Zones & 3 \\
b. & Sub-zone per zone & 2 \\
c. & Number of quadrates per zone $(20 \mathrm{~m} \times 20 \mathrm{~m})$ & 2 \\
d. & Total number of quadrates & 12 \\
e. & Number of regeneration plots per quadrate $(2 \mathrm{~m} \times 2 \mathrm{~m})$ & 10 \\
f. & Total number of regeneration plots on one side of Sutlej & 60 \\
g. & Total number of regeneration plot & 120 \\
\hline
\end{tabular}


The sampling units of $20 \mathrm{~m} \times 20 \mathrm{~m}$ each were selected. Each sampling unit had ten regeneration units of $2 \mathrm{~m} \times 2 \mathrm{~m}$ quadrate as per Cleark (1979). The survey was conducted for counting number of recruits (r), which may be defined as current year's seedlings, unestablished regeneration (u) seedlings other than recruits which has not yet established and with height less than 2 meter and established regeneration (e) plants with height of more than 2 meter. Here four (4) unestablished plants were taken equivalent to one established regeneration for calculating the regeneration per cent. The height of unestablished plants was also measured for the assessment of regeneration.

\section{Regeneration assessment}

The data was analyzed in each sampling plot for the assessment of regeneration status of the species. The established plants of 2500 per hectare were considered satisfactory regeneration. The quadrate was considered fully stocked when it contained one established plant. The data thus collected was analyzed using the formulae given by Chacko (1965).

- Weight Average height $(\mathrm{m})=\frac{\begin{array}{c}\text { Total height of unestablished regeneration }+(\text { No. of } \\ \text { established plants } x \text { establishment height })\end{array}}{\text { Total unestablished plants + total established Plants }}$

- Recruits (r) /ha $\quad=2500 \sum_{i=1}^{\mathrm{ri} / \mathrm{m}}$

- Unestablished regeneration $(\mathrm{u}) / \mathrm{ha}=2500 \sum_{\mathrm{i}=1}^{\mathrm{n}} \mathrm{u} \mathrm{i} / \mathrm{m}$

- Established regeneration (e)/ha $=2500 \sum_{i=1}^{\mathrm{n}} \mathrm{e} \mathrm{i} / \mathrm{m}$

Where
n - Number of sampling units
$\mathrm{m}$ - Total number of recording units in survey
ri - Total number of recruits in each sampling unit
ui - Total number of unestablished plants in each sampling unit
ei - Total number of established plants in each sampling unit

- Establishment index $\left(\mathrm{I}_{1}\right) \quad=\frac{\text { Weighted average height }}{\text { Establishment height }}$

- Stocking index $\left(\mathrm{I}_{2}\right)=1 / 2500 \quad \mathrm{X} \frac{\begin{array}{c}\text { Unestablished } \\ \text { regeneration/ha }\end{array}}{4}+\quad \begin{gathered}\text { Established } \\ \text { regeneration/ ha }\end{gathered}$

- $\quad$ Established stocking per cent $=100\left(\mathrm{I}_{1} \times \mathrm{I}_{2}\right)$

A method was developed to understand the regeneration per cent of the species on the basis of stocking index as: Regeneration per cent $=$ Stocking index $\times 100$ 


\section{Results and Discussion}

The assessment of natural regeneration is an important aspect one has to undertake for initiating silvicultural treatments under forest management systems in forest crops. In present study, Cedrus deodara, Quercus ilex, Celtis australis, Daphne oleoides, Artemisia maritime, Rosa webbiana, Berberis spp., Desmodium spp., Indigofera gerardiana, etc., were the major associated species of $P$. gerardiana.

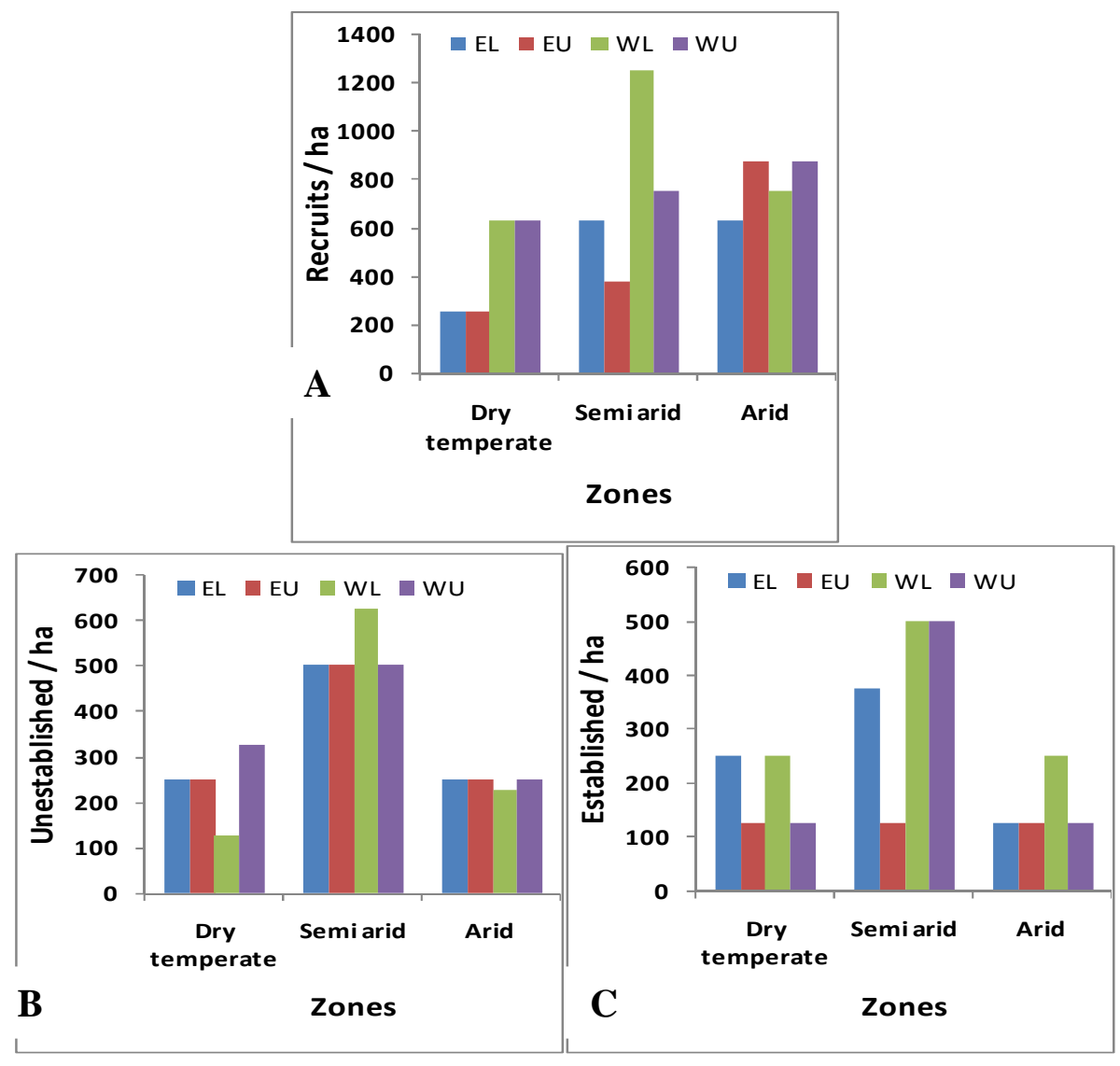

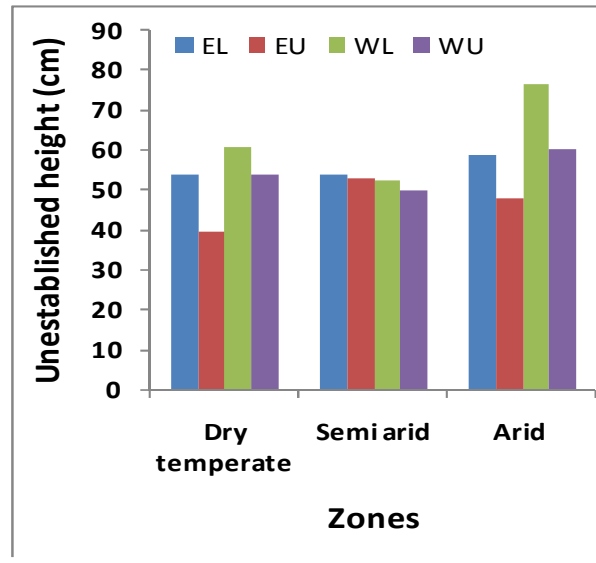

D

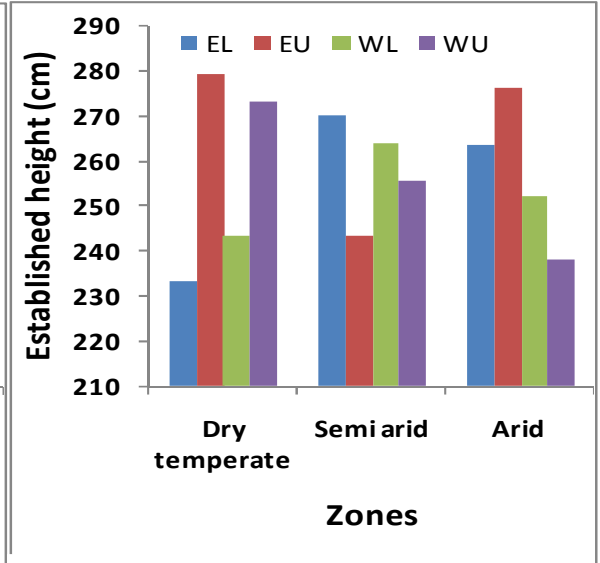

$\mathbf{E}$

Figure 3. Natural regeneration status of Pinus girardiana in different zones of Kinnuar, Himachal Pradesh

( $A=$ Number of recurits/ha; $B=$ Unestablished/ha; $C=$ Established/ha; $D=$ Unestablished height $(\mathrm{cm})$, $E=$ Established height (cm); EL= Eastern Aspect Lower Elevation; EU= Eastern Aspect Upper Elevation; WL = Western Aspect Lower Elevation; WU = Western Aspect Upper Elevation) 
The maximum number of recruits, unestablished and established regeneration was recorded in mid zone II (Semi arid) with elevation ranging from 2180 to $2500 \mathrm{~m}$ amsl on the left bank (western aspect) of the river Sutlej (Fig. 3). However, the maximum unestablished regeneration and established regeneration height was noticed in zone III (Arid) on the left bank with elevation of 2580-2900 m amsl. As far as aspect is concerned, the number of recruits (812.5/ha; Fig. 3A), unestablished regeneration (341.66/ha; Fig. 3B), established regeneration (291.66/ha; Fig. 3C), unestablished height $(58.77 \mathrm{~cm}$; Fig. 3D) and established height $(254.15 \mathrm{~cm} ;$ Fig. 3E) were greater on the left/western aspect as compared to the right/eastern aspect of the area. Further, the zone-III at lower elevation $(2580 \mathrm{~m}$ amsl) resulted in maximum weighted average height (169.05) and establishment index (0.84) while as zone-II at lower elevation (2180 $\mathrm{m}$ amsl) showed maximum stocking index (0.265), establishment stocking (16.04 $\%)$ and regeneration $(26.50 \%)$ on the left bank, i.e., western aspect of the area (Table 1).

Table 1. Natural regeneration status of Pinus gerardiana in different zones of district Kinnuar

\begin{tabular}{|c|c|c|c|c|c|}
\hline Zones/Elevations & $\begin{array}{c}\text { Weighted } \\
\text { average } \\
\text { height }(\mathrm{cm})\end{array}$ & $\begin{array}{c}\text { Establishment } \\
\text { index }\left(I_{1}\right)\end{array}$ & $\begin{array}{l}\text { Stocking } \\
\text { index }\left(\mathrm{I}_{2}\right)\end{array}$ & \begin{tabular}{|c|} 
Establishment \\
stocking \\
per cent \\
$\left(100 \mathrm{I}_{1} \times \mathrm{I}_{2}\right)$
\end{tabular} & $\begin{array}{c}\text { Regeneration } \\
(\%)\end{array}$ \\
\hline \multicolumn{6}{|c|}{ Right bank /eastern aspect } \\
\hline \multicolumn{6}{|c|}{ Zone -I (Tapri, Shongtong) } \\
\hline Lower $(1700 \mathrm{~m}$ amsl) & 151.23 & 0.75 & 0.125 & 8.82 & 12.50 \\
\hline Upper (2020 m amsl) & 78.37 & 0.35 & 0.075 & 3.96 & 7.50 \\
\hline \multicolumn{6}{|c|}{ Zone-II (Peo, Kalpa, Pangi) } \\
\hline Lower (2100 m amsl) & 144.45 & 0.56 & 0.200 & 11.62 & 20.00 \\
\hline Upper (2420 m amsl) & 75.26 & 0.37 & 0.100 & 4.55 & 10.00 \\
\hline \multicolumn{6}{|c|}{ Zone-III (Akpa, Jangi, Leepa) } \\
\hline Lower $(2500 \mathrm{~m} \mathrm{amsl})$ & 91.52 & 0.45 & 0.075 & 4.42 & 7.50 \\
\hline Upper $(2820 \mathrm{~m}$ amsl $)$ & 123.95 & 0.61 & 0.075 & 5.57 & 7.50 \\
\hline Mean & 110.79 & $\mathbf{0 . 5 1}$ & 0.108 & 6.49 & 10.83 \\
\hline \multicolumn{6}{|c|}{ Left bank/western aspect } \\
\hline \multicolumn{6}{|c|}{ Zone -I (Tapri, Shongtong) } \\
\hline Lower (1780 m amsl) & 165.18 & 0.82 & 0.115 & 9.06 & 11.50 \\
\hline Upper (2100 m amsl) & 126.91 & 0.63 & 0.080 & 5.97 & 8.00 \\
\hline \multicolumn{6}{|c|}{ Zone-II (Powari upper, Ribba) } \\
\hline Lower (2180 m amsl) & 131.76 & 0.65 & 0.265 & 16.04 & 26.50 \\
\hline Upper (2500 m amsl) & 115.85 & 0.57 & 0.250 & 15.92 & 25.00 \\
\hline \multicolumn{6}{|c|}{ Zone-III (Akpa, Moorang, Purbani) } \\
\hline Lower $(2580 \mathrm{~m}$ amsl $)$ & 169.05 & 0.84 & 0.115 & 9.31 & 11.50 \\
\hline Upper (2900 m amsl) & 90.79 & 0.45 & 0.075 & 4.57 & 7.50 \\
\hline Mean & 133.26 & 0.66 & 0.150 & 10.14 & 15.00 \\
\hline
\end{tabular}

Singh (2004), while working on Cedrus deodara revealed that the maximum number of recruits and established plants were recorded on northern aspect than southern aspect (Singh, 2004). The finding also gets support from a number of reports as in ponderosa pine (Barrett et al., 1983), fir and spruce in Narkanda forest (Gupta, 1996) and fir and spruce in Shimla forest range (Yashpal, 2006). The overall mean maximum regeneration (15\%) was observed to be higher on the western aspect as compared to that in eastern aspect in the area $(10.83 \%)$. This is probably due to more conducive 
microclimate, optimum moisture content, less human interference as well as grazing pressure on the left than right bank of the river Sutlej. The findings have also been supported by many researchers working on different tree species, i.e., as in Taxus baccata (Shamet and Gupta, 2005), Abies concolor and A. magnifica (Gordon, 1970), silver fir (Singh, 1973) and Englmann spruce (Noble and Alexander, 1977). In long years back, Singh et al. (1973) and Reddy (1963) have reported low natural regeneration potential in Pinus gerardiana in Himachal Pradesh. The scanty/failure of natural regeneration has been attributed to collection of almost each and every cone of the species by the right holders in district Kinnaur as the nuts have high market value and demand. Further, inhospitable climate, summer drought, poor edaphic conditions and deficit soil moisture collectively hamper natural regeneration of this species (Plate 1). At present, roughly 80-120 tones of chilgoza nuts are collected by the right holders and exported to plains every year from the Kinnuar (Malik, 2007).
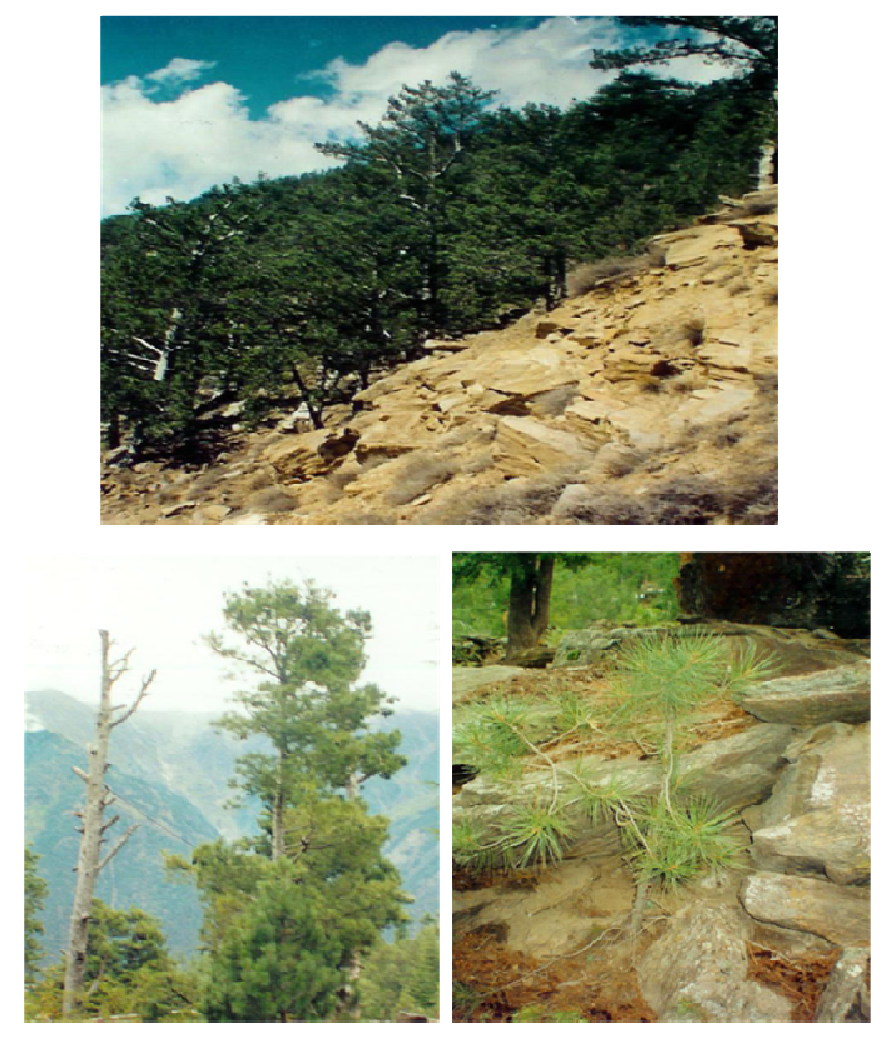

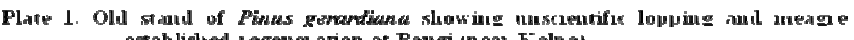
established 1 egenen arion ar Pangi ineas Kalp ai

\section{Conclusions}

The study concludes that chilgoza forest characterized as semi arid zone (mid zone) at elevation ranging between 2180 and $2500 \mathrm{~m}$ amsl showed better regeneration status of this species as compared to other zones of the study area. Overall, the maximum mean regeneration of 15 per cent and establishment stocking of 10.14 per cent was recorded which is considered as failure of natural regeneration in the area. If proper silvicultural measures will not be applied, the further decline in the status of the species will occur in near future. The status of the species is categorized as Near Threatened Red List (2008). In view of poor natural regeneration status and stand condition, the species deserves to 
be included in Critically Endangered species category in Indian Himalayan region. There is an immediate need to protect this species from over harvesting, grazing and other destructive activities. Besides in-situ conservation and management, mass scale afforestation of this species with the participation of local communities on potential zone need to be done. For that, a suitable strategy and action plan including sustainable harvesting methods should be prepared and executed, effectively. Local communities need to be made aware about conservation and sustainable utilization of P. gerardiana.

Acknowledgements. We thank Dr. S.D. Bhardwaj, Dean and Head, Silviculture and Agroforestry, Dr. Y. S. Parmar University of Horticulture and Forestry, Nauni, Solan (H.P.) India, for providing necessary facilities and consistent encouragement. ARM and JSB thank the Director of G.B. Pant Institute of Himalayan Environment and Development, Kosi-Katarmal, Almora (U.K.), India, for providing key facilities during writing of the manuscript.

\section{REFERENCES}

[1] Gupta, B.N., Sharma, K.K. (1975): The chilgoza pine, an important nut pine of Himalayas. - Wans Year Book 1: 21-32.

[2] Gamble, J.S. (1902): A Manual of Indian Timbers. - Humphrey Milford, Oxford University Press, p. 709.

[3] Chib, S.S. (1978): Kanauar of the trans-Himalaya. - Ess Ess Publication, New Delhi, p. 110.

[4] Malik, A.R. (2007): Studies on natural regeneration status and nursery technology in Chilgoza pine (Pinus gerardiana Wall.). - Ph.D. Thesis. Dr. YS Parmar University of Horticulture and Forestry, Nauni, Solan, India, p. 216.

[5] Sehgal, R.N., Khosla, P.K. (1986): Chilgoza pine the threatened social forestry tree of dry temperate Himalaya. - National Symposium on Research in Social Forestry for Rural Development, January 1-2.

[6] Tandon, J.C. (1963): Revised working Plan for the Kinnaur and Kochi forests (Upper Sutlej valley). - Himachal Pradesh, 1961-62 to 1975-76.

[7] Singh, R.V., Khanduri, D.C., Lal, K. (1973): Chilgoza pine (Pinus gerardiana) regeneration in Himachal Pradesh. - Indian Forester 3: 126-133.

[8] Sehgal, R.N., Sharma, P.K. (1989): Chilgoza: the Endangered Social Forestry Pine of Kinnaur. - Dr. YS Parmar University of Horticulture and Forestry, Nauni-Solan, India. Technical Bulletin No. FBTI 1: 1-8.

[9] Dogra, P.D. (1964): Gymnosperms of India-II. Chilgoza pine (Pinus gerardiana Wall.). - Bulletin of the National Botanic Garden 109: 446.

[10] Singh, N.B., Chaudhary, V.K. (1993): Variability, heritability and genetic gain in cone and nut characters in chilgoza pine (Pinus gerardiana wall.). - Silvae Gen. 42: 61-63.

[11] Singh, P.L., Gupta, N., Singh, A.L. (1992): Deterioration of physico-chemical properties of chilgoza (Pinus gerardiana Wall.) seed during storage. - Indian Journal of Plant Physiology XXXV (3): 231-237.

[12] Sharma, V. (2005): Effect of artificial stratification of Chilgoza pine (Pinus gerardiana) seeds on its germination. - In: Verma, K.S., Khurana, D.K., Christarsson, L. (eds.) - Short Rotation Forestry for Industrial and Rural Development, ISTA, Nauni, Solan, India, pp. 266-270.

[13] Malik, A.R., Shamet, G.S., Ali, M. (2008): Seed stratification of Pinus gerardiana: Effect of stratification duration and temperature. - Indian Forester 134 (8): 1072-1078.

[14] Malik, A.R., Shamet, G.S. (2008): Germination and biochemical changes in the seeds of chilgoza pine (Pinus gerardiana Wall.) by stratification: an endangered conifer species of north-west Himalaya. - Indian Journal of Plant Physiology 13(3): 278-283. 
[15] Malik, A.R., Shamet, G.S., Ali, M. (2009): Germination and seedling growth of Pinus gerardiana in nursery: Effect of stratification period and temperature. - Indian Journal of Forestry 32(2).

[16] Reddy, C.V.K. (1963): Tour note of Kinnaur Forest Division. - May 1963.

[17] Leoppold, A.C., Andruus, R., Finkeldey, A., Knowles, D. (2001): Attempting restoration of wet tropical forests in Costa Rica. - Forest Ecology and Management 142: 243-249.

[18] Smale, M.C., Whaley, P.T., Smale, P.N. (2001): Ecological restoration of native forests at aratiatia North Island. - New Zealand Restoration Ecology 9: 28-37.

[19] Hardwick, K., Healey, J.R., Elliott, S., Blakesley, D. (2004): Research needs for restoring seasonal tropical forests in Thailand: accelerated natural regeneration. - New Forest 27: 285-303.

[20] Carnus, J.M., Parrotta, J., Brockerhoff, E., Arbez, M., Jactel, H., Kremer, A., Lamb, D., Hara, O., Walters, B. (1979): Planted forest and biodiversity. - J. For. 2006, 104(2): 65-77.

[21] Clark, F.R. (1979): Comparison of regeneration survey designs utilization plot sizes. Typed mass, Ontario Ministry of Natural Resources, Toronto p. 26.

[22] Chacko, V.J. (1965): A manual of sampling techniques for forestry surveys. - Manager Publication, Delhi, p. 172.

[23] Singh, A. (2004): Biometric studies on stand characteristics of different aged deodar forests. - M.Sc. Thesis, Dr Y S Parmar University of Horticulture and Forestry, NauniSolan, India, p. 107.

[24] Barrett, J.W., Martin, R.W., Wood, D.C. (1983): North West Ponderosa pine and associated species. - In: Burns, R.M. (ed.): Silvicultural systems of the major forest types of the United States USDA Forest Service Handbook 445: 16-18.

[25] Gupta, N.K. (1996): Appraisal of vegetational pattern of Shimla district through remote sensing with special reference to the ecology of fir-spruce forest. - Ph.D Thesis, University of Horticulture and Forestry, Nauni, Solan, India, p.113.

[26] Yashpal, S. (2006): Studies on stand parameters and natural regeneration status of silver fir and spruce in Himachal Pradesh. - M.Sc. Thesis, Dr. YS Parmar University of Horticulture and Forestry, Nauni, Solan, India, p.110.

[27] Shamet, G.S., Gupta, N.K. (2005): Survey, regeneration and planting studies in yew (Taxus baccata) - An endangered medicinal species of Himalaya. - Report National Medicinal Plant Board, Government of India, p. 25.

[28] Gordon, D.T. (1970): Natural regeneration of white and red fir. - US Forest Research Paper No. PSW 58: p. 32.

[29] Singh, R.V. (1973): Forests regeneration of spruce and Silver Fir. $-11^{\text {th }}$ Silvicultural Conference, F.R.I., Dehradun, Vol. II: 432-440.

[30] Nobel, L., Alexander, R. (1977): Environmental factors affecting natural regeneration of Englemann spruce in the central rocky mountains. - Forest Science 23(4): 421-429.

[31] IUCN (2008): Red List of Threatened species. - www.iucnredlist.org. 